\title{
Creation of Identities in Political Conflict: Kenya's Newspaper Discourse
}

\author{
Mary Karuri", Prof. Peter Muriungi \\ Chuka University, P.O Box, 109, 60400, Chuka. Kenya
}

\begin{abstract}
This article looks into the construction of political identities in the discourse of two Kenyan newspaper headline stories covering the period of the Kenyan Coalition Government formed in 2008 to stem political conflict that arose after the disputed elections of 2007.It focuses on the two principals of the coalition government, President Mwai Kibaki and Prime Minister Raila Odinga. Using a Critical Discourse Analysis(CDA) approach, the study analyses newspaper headline stories of the two leading newspapers in Kenya, Daily Nation and The Standard to gauge how the newspapers created identities for the two principals in the context of the political situation that existed then. The Prime Minister (PM) Raila Odinga is seen as a hero but also a victim of political forces. He is also evaluated as a peacemaker who quells conflicts brought about by his co-principal. President Kibaki, on the hand is depicted as an opportunist, anti-reformist and an ineffective leader. The newspapers exploit discourse strategies such as evaluative lexicon, structuring, schematic form and metaphor to create the identities and to persuade the audience to adopt a certain ideological stance.
\end{abstract}

Keywords: Discourse, Political Conflict, Constructed Identities, CDA, ideological stance

\section{INTRODUCTION}

People create their identities as they engage in discourse and situate themselves in social relationships. This means that identity construction is a social process not an individual one (Frogner, 1999). Identities are not possessed but constructed through interaction and language is the most important symbol for expressing and negotiating identities. While many times identities are 'ascribed', 'assumed' or 'rejected' in negotiations, this is not always possible (Fina, 2011). In media news reports for instance, people are positioned into roles which they may not refute. Put in another way, the privileged position of the media in terms of deciding what to present means that they can depict people in a way that may be very hard to change.

Identities are not just social constructions but also cognitive structures (van Dijk 1998). In van Dijk's view, the social discursive situations provide opportunities for the enactment of the cognitive structures which are fairly fixed and stable. Conversation analysts have opposed the cognitive aspect and argue that it is the interactants that create 'membership categories' in conversations. But as Fina (2011) argues, both views are complementary because on one hand, identities cannot entirely be categorized by focusing on discursive processes since this would be to ignore prior knowledge, beliefs, ideologies and other cognitive aspects shared by the interactants. On the other hand, the exact nature of the cognitive basis for categorization is not clear. In newspapers, we do not have negotiated identities since the media has the privilege of forming its own opinion without the input of those that they describe, or the other readers who may be influenced to view characters in the same way as the media (Fina, 2011).

Newspapers create identities for themselves by identifying with certain ideologies (Hardman, 2008). Hardman explains how British newspapers create their own identities and those of political actors by taking certain ideological stances and in the process, persuade their audience to identify with the perspectives and make judgments accordingly. Althusser (1971) argues that the media makes people ideological subjects by constructing social and political positions for them through interpellation. However, Althusser'sclaim that people always accept the subject positions allocated to them may debatable when it comes to creation of identities in newspapers because there is no room for contestation of identities in newspapers.

In the process of ascribing of identity, one group may dominate another as it ideologically positions itself in the social space in relation to another group. For instance, male domination in conversation 
has been a topic of study for long (Tromel-Plotz, 1998Yieke, 2007). The studies show tendency of power imbalance in favour of men in conversations. For instance, Yieke (2007) observes that men dominate meetings in terms of raising and changing more topics than women who are relegated into supporting men's topics. Male domination, however, can actually be practised by both men and women. For instance, Ndambuki (2010) looks into the contradiction between women discourse as they describe themselves and what they actually do in the society. Centering on 'agency' (capacity for people to act freely but within the constraints of society), the study observes that both the women in women groups (in Makueni District) and politicians portray women as lacking in agency while their very actions communicate otherwise. They are involved in many activities such as provision of child care, food and health care, yet they portray themselves as helpless. It would seem that women's discourse is culturally situated and they are keen on justifying the belief held in many patriarchal societies that they (women) are poor, ignorant, powerless and illiterate. Such discourse of negative self-portrayal by women can only serve to perpetuate unequal power relations between men and women in society. The study (Ndambuki, 2010) uses grammatical categories of modality, voice and pronouns to bring out the gendered social relations.

Both Yieke's (2007) and Ndambuki's (2010) studies affirm how language, being a social practice blends into other social practices such as domination based on gender. Both men and women (in Ndambuki's study) take domination as 'natural' and even when women's actions show that they are indeed in charge of some noble actions, they describe themselves in discourse of helplessness to conform to the cultural expectations of how women should be. As for the men in Yieke's study, they 'naturally' perform their roles as men to dominate women. Through discourse, the ideology of male superiority is confirmed and perpetuated in both studies.

This paper looks into the way news writers use language to construct identities for political actors which reflects the particular paper's interpretation of the country's politics and ideological stance. The study covers the period of the grand coalition government formed in Kenya in February 2008 through mediation by the former UN Secretary General Kofi Annan, between the two leading political parties; Orange Democratic Movement (ODM) and Party of National Unity (PNU) led by Raila Odinga and Mwai Kibaki respectively. The coalition government was formed to stem further crisis after the country was rocked in violence following the elections that were believed to be flawed. Kibaki was the president while Raila was the Prime Minister in a cabinet of 42 ministers and 52 assistant ministers from both sides of the government. The fact that the coalition government was formed in a crisis means that it was a forced coalition and consequently, it was characterized by conflicts, with the two principals constantly engaged in battles of political supremacy. The reporting of the conflicts in the Daily Nation and The Standard revealed the papers' political leaning and inevitably, their stance on the two principals.

\section{Methodology}

Newspapers written in the five-year period of the coalition government were sampled from University libraries. Theoretical sampling was the done to come up with the headline stories that would be considered 'political' using a criterion proposed by Chilton and Schaffner (2011). The criterion proposes that political discourse should have aspects of legitimization, coercion and representation. In this study, coercion was taken to approximate closely to the persuasive discourse that newspapers use to make their point. Further, newspaper headline stories that evaluated the two principals of the grand coalition were sampled for analysis. The texts obtained were analyzed through CDA approach where the micro (syntactic structure, lexicon, and semantics) and macro (schema, whole arguments, and pragmatic features) were considered.

\section{DisCuSSION}

This section categorizes and discusses the identities of the two principals of the coalition government of Kenya as they were portrayed in the two newspapers The Standard and Daily Nation. Through a combination of discourse strategies, the newspapers present the two leaders in ways that point to the newspapers' stance on the political leadership of the country.

\subsection{Prime Minister Raila Odinga as Hero and Victim}

When Kibaki became president in 2002, Raila felt shortchanged because Kibaki had allegedly reneged on a memorandum of understanding that the two had agreed on when they came together under the umbrella of NARC party to form a government that dislodged the ruling party KANU from 
power. By the time the disputed elections were held in 2007 Raila had become the leader of opposition. After the elections, he became the prime minister and a co-principal to president Kibaki in the Grand Coalition Government. In the Coalition, the PM and the president clashed throughout over political supremacy. The newspapers depicted the PM as both a hero and a victim of political intrigues in the headlines and subsequent stories.

In the headline, The Return of Raila ${ }^{1}$, the use of 'return' gives the idea of one coming back to finish some task he had left. Interpreted in the political context of that time, the headline captures Raila becoming a prime minister in the Coalition Government as a 'return' to political limelight. The story that follows creates an image of a hero:

\section{Prime Minister RailaOdinga is once again the centre of national attention after ending up in a government in which he has enough control to deliver some of the crucial changes Kenyans have long sought (Text 1)}

The description of the PM in text 1 serves to have the reader see the PM not just as co-principal in the Coalition Government but one with a much higher stake and one in whom the country has great expectations and has long waited for. The choices of lexicon describing him as being at the "centre of national attention' gives the idea of a hero without equal and one whom everybody is looking up to. This description is given using a declarative sentence with a copular verb 'be' (Prime Minister is once again...) making it a categorical declaration and hence limiting the reader's view of the Prime Minister. It is also notable that in using the phrase 'once again' the writer suggests that the PM has had such moments of being the centre of attention before and this portrays ever-green personality who has bounced back to the public limelight and all eyes are on him. This argument is developed further in the story:

The PM, in public speeches and in an exclusive interview yesterday,

indicated he intends to run one government, not two, with President

Kibaki to deliver the transparency, efficiency and accountability

in service delivery.(Text 2)

In text 2, the PM is presented as the initiator of action; he is the subject and the agent in the clause 'he intends to run one government .... with President Kibaki......'. President Kibaki on the other hand is juxtaposed as an object of preposition or an instrument. It gives an image of one who is being 'carried along', and not one to be actively involved in running the country. Grammatical styles of referring to characters can reveal the underlying attitude of the writer/ speaker (Leeuwin, 2007). By making the president an object in the preposition phrase and the minister the subject of the sentence, the writer is in essence making a subjective evaluation of the two leaders. The continued description of the PM further elevates him to an enigmatic level, as the description in text 3 shows.

The events of last week and Raila's promissory and reconciliatory tone, cast the image of a man at the junction of history. (Text 3)

The whole story is an analysis of the PM and is dedicated to represent him as an embodiment of greatness - he is 'at the junction of history' where he can transform the country and there is so much expectation from him. Further in the story, there is parallelism between the premier and the first Kenyan prime minister, Jomo Kenyatta:

Raila, being the second Prime Minister after Mzee Jomo Kenyatta for one year after independence is the talking point. Raila, with his ability to mobilize, is expected to take centre-stage on seeing through some of the reforms the coalition has promised. (Text 4)

By drawing parallelism between Raila and Jomo Kenyatta, the writer is recontextualising the situation in order to make his point. He seeks to bring into focus two defining moments in Kenyan history: after independence and after a near-civil war (due to the post- election violence of 2007-2008). The subtle message seems to be that both moments needed great men to take the country forward. The 
heroization of the premier serves to leave the reader with no doubt about whom the right person is. The use of the declarative clause and the definite article 'the' (Raila... is the talking point) makes the proposition categorical and an indisputable fact. If he is 'the' talking point, then there can be nobody else like him. The PM is also identified with 'ability to mobilize'. This representation of the premier as a hero has ideological undertones and the paper seems to implicitly suggest the direction the country should take. Further in the story, the writer implies that the greatness of the PM is so profound that he will be struggling not to overshadow the president.

Raila is also the object of attention because, given his packed diary and active political life, he will probably be trying to get as much public exposure without overshadowing the president. (Text 5)

The elevated portrayal of the prime minister continued throughout the period of the Grand Coalition Government and this was especially so in The Standard newspaper. For instance, under headline, Raila on Kibaki ${ }^{2}$ The Standard gives accolades to the PM in a manner different from what is expected in news reports. The story is based on an interview that the PM held with Los Angeles Times journalists against a backdrop of conflict between him and the president over head of civil service's office which was seen to be undermining the authority of the PM. The opening paragraph of the story describes him thus:

Prime Minister Raila Odinga's language and disposition in the Grand Coalition Government casts the picture of a man who, although he believes his victory was stolen, has resolved to live to fight another day. But going by an exclusive endyear interview he granted the The Los Angeles Times, behind the façade, there is more to Raila who is perceived as patient and calculative schemer. (Text 6)

The kind of evaluation given in text 6 goes beyond just reporting to a deeper political purpose of creating an image of a man who has been wronged by the political system of his country but who has not been vindictive and is capable of springing surprises in the political scenery in future. It is notable that the evaluative adjectives of the PM as "patient" and "calculative" are given in an agentless passive relative clause - 'who is perceived as patient and calculative schemer'. In the absence of 'who' perceives the PM that way, the writer wants it to appear as a general perception of the PM that cuts across the populace. In other words, the traits attributed to the PM are general knowledge to everyone. This kind of description is geared toward persuading the readers to align themselves with the view of the paper about the PM and in the bigger political scenario, to further the paper's ideology about the political leadership of the country.

The Standard headline Was this man given a long rope to hang? ${ }^{3}$ was written in reference to the task the prime minister was assigned of reclaiming the Mau forest in the rift valley. This was a delicate assignment as it would involve evacuation of people from the forest in a region which had voted overwhelmingly for the premier in the 2007 general elections. The interrogative form of the headline makes it interactive and is bound to raise curiosity and get the audience to 'engage' with the paper and ascertain the 'truth' of the proposition. The metaphor in the question makes the proposition weighty and the audience is persuaded to read on to 'get answers'.

A look at the story reveals a critical analysis of the prime minister's possible political predicaments.

Prime minister RailaOdinga is juggling three balls in the air and if lets one fall, he could be political minced-meat for his rivals in the 2012 presidential election. He could be the proverbial politician who was given a rope to hang and he did not disappoint. He could also emerge victor and legitimate "owner" of a new Kenya into whose hands history has thrust the opportunity to help deliver.

(Text 7)

The opening paragraph of the story is a mixture of metaphor, symbolism and philosophy. The premier is presented both as a hero who stands a great chance in history to prove his might and as unassuming prey set up by the president to chart the course for his own destruction. He has to make a delicate balance between his ministerial responsibilities and his political survival. The image of three balls 
juggling in the air captures the precarious situation of the premier and the 'minced meat' metaphor portrays him as a potential victim of his political rivals who will destroy him if he makes a wrong move. Indeed, the language used in the analysis of the premier's situation seems to include him both as the centre of concern but also as a beneficiary of the 'advice' 'offered' for his presumed political dilemma. The whole story is woven into a discourse of ambivalence on Raila's possible triumph or failure depending on how he handles his situation. Before the story begins, the paper puts a billboard that sums up the apparent difficult political situation faced by the premier in bulleted format as follows:

- Odinga is juggling three balls and if just one falls, it could burn his chances in 2012

- If Raila fails, Kibaki can say he gave him a chance, if he succeeds, it will rescue his own tattered legacy

- Why, with an expanded portfolio and refined mandate, Raila could make or break himself

- Why Raila's supporters are taking Kibaki's recent show of goodwill with a pinch of salt

- How supervision of evictions from water towers could fasten divisions in ODM and hurt PM (Text 8)

The billboard summarizes the premier's possible political predicaments and serves in guiding the reader's interpretation of the situation before he reads the whole story. Notable in the billboard is its discursive character seen in the use of 'if' 'why' and 'how' making it conversational and persuasive. The depth of the story brings out the issues raised in the summary, discussing the PM with a mixture of hope in what he can do as a prime minister but also with fear of his possible self-destruction. The writer lays an evaluative framework of the PM by his reference to PM's earlier achievements as captured in text 9 .

In 2003, Raila who played a leading role in getting President Kibaki elected was roads minister and supervised the demolition of palatial buildings on land initially set aside for by-passes in Nairobi. (Text 9)

The embedded defining relative clause 'who played a leading role in getting President Kibaki elected' is inserted to reinforce the PM's positive character but more importantly it makes reference to his role in 'getting the president elected'. Looking at the assertion from a historical context, there was a popular notion that Raila was instrumental in Kibaki's presidential victory in 2002 elections because at some point, he endorsed Kibaki as the sole presidential candidate for NARC. The writer of the story is hence referring to the popular belief in order to appeal to the reader to evaluate the premier positively. The whole story develops into an evaluation of the premier as a hero but also a victim of rival political forces led by president Kibaki.

The writer's misgivings about the PM's political future are captured in the following text.

But the question is: Will he pull through with what is on his hands? The president has cast him as senior to cabinet members apart from himself.

(Text 10)

But Raila says he is ready to pay the political price of helping change Kenya, arguing the task at hand was more beneficial to Kenya. (Text 11)

The question in text 10 makes the reader part of the discursive event about the premier but in text 11 , the writer provides the answer to his own question and the reader's role in the 'discussion' is relegated to agreeing with the writer's point of view. The selflessness and hence the heroization of the premier is once again brought to fore by the claim that "he is ready to pay the political price of helping change Kenya". The accolades on the PM continue throughout the story.

If this fails, president Kibaki will have achieved two goals; his display of willingness to let Raila push the wheel of development, but still claim the fruit of success and use it to rebuild his legacy which ails from the after-taste of postelection violence (Text 12) 
In text 12 , it is notable that the president is portrayed as one who stands to gain if the PM fails to deliver. The story further develops to a deep analysis of the PM expressing fears and cynicism on the PM's role as a supervisor of ministerial functions and describes his role as 'tricky' because the cooperation of the other ministers is not guaranteed (text 13)

This is tricky for Raila because the success of the programs would depend on the good will of other Cabinet ministers and movers of government whom the National Accord gave him powers to supervise and coordinate their operations.(Text 13)

They include the President and other leaders who just a few months ago would not hear him out when he lay claim to the office of leader of Government Business in Parliament, or even when he insisted in public he came first before the Vice President KalonzoMusyoka.(Text 14)

The other side of Government sneered at him and told him he was day-dreaming (Text 15)

In text 13, the writer revisits an earlier issue of conflict between the PM and the president to back his (the writer's) position that the PM is likely to fall victim to the same forces that had earlier opposed his bid to be the leader of government business in parliament. In text 14, the writer uses 'sneered' to further describe the behaviour of the 'Other' leaders towards the PM to positively endear him to the reader while also seeking the reader's sympathy for the PM for the apparent mistreatment by 'Others'.

The writer's concern about the PM's fate in the country's politics is seen in the sustained argument about the premier's precarious political situation. In text 15, the issue of Mau forest and its political implication on the PM is brought up. The writer makes reference to the PM's political popularity in the Rift Valley by the claim that he is being told to evacuate the very people who 'probably died for him', in the 2007/2008 post-election violence. This argument reinforces the PM's image of a national hero but one who is also prone to political destruction if he is not careful.

Raila's second ball in the air is his grassroots popularity especially in the rift valley where he was handed the task of clearing the swathes of forest land parceled out to peasants and the mighty and the moneyed. Critiques argue that if Raila mishandles this, in 2012 he will be told, as is the case now, he is turning against the same people who voted, and probably died for him.(Text 16)

But in private, some of his supporters think that even though Kibaki has "certainly warmed" up to Raila and had been with him recently in many joint functions, the president is letting Raila do the spadework then he leaps the fruits (Text 17)

In text 17, the president's apparent positive attitude towards Raila is treated with cynicism because it is interpreted as selfishness and exploitative, purely meant to benefit the president himself. In text 18, the writer gives his verdict, metaphorically by warning that if the PM is not able to handle the apparent perilous situation, he would be like 'a giant standing on mosquito feet' meaning that he would have no support of the people and his might would not help his bid for presidency. Although the presidential elections were three years away, the writer weaves his story to connect the political events then to the elections in order to present the PM as a suitable candidate but one who was in an intricate situation that could jeopardize his chances of leading the country.

If he loses it as some argue he could by 2012 end up a giant standing on mosquito feet. ....... But either way his friends and enemies will be watching his juggling balls, each saying a different player. (Text 18)

The story is so dedicated to a thorough evaluation of the PM that it is far from being a news report merely capturing his undertakings in the coalition government.

The headline, Why they want Raila out ${ }^{4}$, also brings out the PM as a target of several political players and portrays him both as a hero and a victim of Kenyan politics. The context of the headline was in early 2011 and the general elections were to be held the following year. However, the conflict between the two sides of government at that time was occasioned by the PM's rejection of the president's nominees to some key constitutional positions. These were positions of Chief Justice, 
Attorney General, Director of Public Prosecution and Controller of Budget. Like many other conflicts, the stalemate on the nominees was interpreted in light of Kibaki succession where Raila's opponents were seen as keen on blocking his bid for presidency.

A summary of the situation is given strategically immediately below the headline which extends the twin theme of hero and victim in the description of the PM as the 'common adversary' and 'seasoned combatant' captured in text 19.

As the Kibaki succession gains momentum, the PM is turning out to the common adversary uniting politicians opposed to his bid in 2012. Will the seasoned combatant weather the gathering storm? (Text 19)

The story furthers its argument by extensively quoting multiple voices that agree with the line of thought that the PM is a common target among politicians and notably, among the quoted are two university lecturers to lend credit to the argument. Only one person is quoted as having a different opinion about the PM. On the second page of the analysis of the premier, the paper writes another sub-headline; 'Why raila is a common foe for all' and this serves to reinforce the major headline by extending the discussion about Raila's unique position as a 'common foe'. The sub heading is followed by a summary in bigger print than the rest of the text to highlight the arguments made in the story:

Intrigues surrounding Kibaki's succession come to fore as opponents use individual and collective grievances against PM as ammunition to stop his grand march to State House (Text 20)

The whole story engages in heroization of the premier as it also portrays him as a victim of political wars waged by his rivals. While this story may not be different from others that have engaged in the analysis of the PM, it is the timing of it that draws attention. The writer decided to topicalize Kibaki succession at a time when elections were not near. In fact, the debate in parliament on which this story was based was about appointments to some constitutional offices but in this story, the whole issue is tilted to become the issue of succession. By topicalizing succession and presenting the PM as the center of politics, the writer makes a bigger statement as who he deems to be the right person to ascend to presidency. And the writer's choice of opinion givers on the issue affirms this. For instance, Professor Wanjala of Nairobi University is quoted describing the PM thus:

"He is the dynamo around which our politics revolve and elicits both love and fear. By virtue of his character and style, he determines our politics and our political discourses" (Text 21)

Political alignments, as the 2012 elections approached, saw Ruto, a former ally to the premier getting closer to president Kibaki after falling out with Raila. Against this background, the Daily Nation had the headline, Will Raila survive Kibaki's Mr. Fix It ? $^{5}$ The rhetorical proposition presupposes that the answer is implied in the question and it is a matter of general knowledge. Writers present texts in interrogative forms to preempt the readers' 'questions' and consequently come in to 'address' the questions. This way, the author assumes a dialogical character 'engaging with the audience rather than simply writing a monologic report' (Discourse and Society, 20, 1: 108). Hardman (2008) refers to this kind of engagement as 'synthetic mutual engagement' but observes that it helps in foregrounding a proposition. The first paragraph of the story is an authorial commentary of the state of affairs in political developments told in a categorical tone:

Eldoret north MP Williama Ruto is President Kibaki’s new Mr Fix It.

And the suspended Higher education minister's mandate in the new

assignment is clear: Keep Prime Minister RailaOdinga in check (Text 22)

The first sentence in the text, 'Eldoret North MP William Ruto is President Kibaki's new Mr. Fix It' carries the copular verb 'be' which is used to express modality within texts and as previously observed, its complementation reflects a high degree of certainty of the speaker (Biber et al, 2002). The mood in the above proposition is indicative; that is, a certain state of affairs is in existence and there is no question about it. This serves to constrain reader's own judgment of the character in question. The choice of words 'Mr. Fix it' is derogatory and meant to portray Ruto in negative light and by extension, the president himself. Herman and Chomsky (1988) observe that words can be used to express negativity and manufacture consent from readers. The story continues with the negative depiction of William Ruto and his presumed elevation by the president. 
During the rally at 64 stadium, all protocol was ignored and Mr. Ruto sat next to the president and took the honor of welcoming the head of state to address the gathering. Never mind there were several cabinet ministers in attendance.(Text 23)

The alleged developing closeness between the president and William Ruto is interpreted as a conspiracy to undermine the PM. Hence, the political battle between the two principals is presented in a way that makes Raila appear like a victim of political machinations between his former ally, $\mathrm{Mr}$ Ruto and president Kibaki as in the following texts.

It is clear what president Kibaki wants to extract from his arrangement. Mr Ruto is perphaps the only politician at the presidents disposal who has the courage and number to take on Mr Odinga. (Text 24)

But what is in it for Eldoret North MP? And what do the Kibaki loyalists, the people who have been fighting serious political battles started and propagated by the same Mr. Ruto, feel about the new development? Has PNU endorsed the new found ally or do some people feel jilted? (Text 25)

Text 24 continues with the conspiracy narrative while in 25 , the writer employs conversational style by asking questions even as he insinuates that Ruto's alleged friendship with the president is bound bring disquiet to PNU loyalists who may feel the president is giving Ruto too much attention. The writer brings up the issue of ICC, which has no relationship with the matter at hand in order to make a point.

However, the eloquent MP's days in the sun could come to an abrupt end should the ICC prosecutor Luis Moreno Ocampo get the judges' nod to open a case against the six Kenyans accused of having played a leading road in the 2007 post elections violence. (Text 26)

The embedding of the ICC into this story seems calculated to 'remind' the reader that Ruto has a case hanging on him and hence the schemes he has with the president against Raila will not last long. In this story hence, the writer presents the PM as a target of conspiracy by the president and William Ruto through persuasive engagement with the reader and interweaving of unrelated issues to make a point.

\subsection{Raila as a Peacemaker}

The newspaper writers have at times portrayed the PM as reconciliatory in times of crisis. For instance, inThe Standard headline, The Battle goes to parliament ${ }^{6}$ the conflict between the President and the Prime Minister over the leader of house business committee in parliamentis introduced. In the second paragraph, the Prime Minister is presented as reconciliatory as text 27 shows.

There was, however, a ray of hope when raila sought to reassure the

country the dispute would be resolved amicably (Text 27)

The combination of the existential 'there' and the copular 'be' denoting an indicative mood gives a subjective assessment of the situation. Semantically 'there' as used in the text is empty and only acts as grammatical subject but does not refer to any concrete place. When used in this generic sense, it can give the impression of consensus about a proposition and serve an ideological purpose for the paper. In this text, there is suggestion of a general agreement that the premier's intervention was nationally significant.

A similar evaluation of the PM is made in Daily Nation under the headline Raila urges calm as PNU plots offensive ${ }^{7}$. In the headline, the writer employs syntactic parallelism to portray the PM as the sober partner in the coalition while juxtaposing him with his PNU counterparts who are shown as the aggressors. The first paragraph captures the depiction of the PM hence:

Prime Minister RailaOdinga yesterday moved to calm the waters as the new row over President Kibaki's nomination of top judicial officials provoked serious rifts in the government. Mr Odinga offered to meet the President in an effort to solve dissgreements away from public exchanges (Text 28) 
Text 28 would make one not acquainted with Kenyan politics think the PM was an outsider (in the sense of the particular conflict) coming to arbitrate political conflict of others. But the conflict was precisely because the PM and the president could not agree on the nominees picked for judicial and other offices. Put in another way, it is curious for the media to evaluate the PM as arbiter in the very thing that he and his co-principal have created. In both texts above, Raila is the agent in the actions of 'calming the waters' and 'offering to meet the president' while the President in both clauses is an object. This in effect elevates the PM as a well-meaning and a selfless peacemaker.

\subsection{President Kibaki as an Ineffective Leader}

Very few stories in the two papers explicitly described the character of the president as they did the PM. That means he did not attract as much media attention as Raila at a personal level. However, the general view of the president captured in the newspapers especially in The Standard was one of an ineffective leader who was actually in the way of his co-principal, Raila Odinga, perceived as more progressive. Two particular stories by The Standard, A President in $\mathbf{d e b t}^{\mathbf{8}}$ and $\mathbf{A}$ man with one option' are evaluative of the president as one whose leadership prowess is questionable. The choice of words in 'A president in debt'gives an image of a man who is besieged by debts and is therefore bankrupt. This was in apparent reference to the political indebtedness of the president to the people who had helped him rise to power. In presenting Kibaki as having debts, the writer alludes to an important feature of discourse; marketization, which Fairclough (1995a) refers to as one of the pervasive features of the contemporary orders of discourse. In marketization, consumption is the dominant force in the society (Brownlie et al, 1999) which extends beyond the commercial realms to other spheres of human society such as relationships, politics and family. Just as in trade and commerce, commercial logic is adopted by politicians to cater for a political market in the citizenry as the consumers. By portraying Kibaki as one laden with debts, the writer in effect shows him as a politician who cannot navigate the political market well, pay his political 'suppliers' in order to remain afloat in politics. Just like businesses fail when they cannot pay their debts, Kibaki won't make much headway.

The market logic in politics is also seen in Moufahim (2007) where he explains how an extreme right party (Vlaams Blok/VlaamsBelang) in Belgium tries to market its political products to its populace for electoral success. He provides a market-related explanation of how the party surmounts its racist tendencies to persuade the people to vote in its favour. It advances its ideology through a marketing strategy. In the story, A president in debt, the writer also looks at politics in commercial terms and Kibaki as a poor manager of political resources. In the continuing story, the writer makes some moral evaluations about the kind of legacy that Kibaki would leave after his term expired, notwithstanding he had done only two years of his second term.

After a tumultuous decade in office, will Kibaki succeed to 'repair' his image and leave behind a worthwhile legacy? (Text 29)

The evaluative adjectives of the president as having a 'tumultuous' term and the fact that he needs to 'repair' his image portrays him as one who should not have been leading in the first place. The writer makes his views conversational by posing them as a rhetorical question whose answer should be 'obvious' to everyone. Rhetoric questions provide a quasi-conversation between the readers and the writer (Moufahim, 2007). The positioning of the dependent clause in the sentence initial position foregrounds the negativity in 'tumultuous'. Such an observation of the presidency made quite early in his second in term office dents the image of the president and ideologically betrays the political leaning of the paper. The story goes on to describe the president as one who is "politically indebted to many people" and that "these are not easy debts he can run away from". The story concludes:

Indeed, the list of Kibaki's creditors is long and soon they will

be making a beeline to his political court reminding him

it is payback time before he leaves office. (Text 30)

The use of 'indeed' emphasizes the idea that Kibaki's creditors are numerous. The imagery of 'political court' is also supposed to portray him as a man on trial because of his 'debts'. This story was carried in a Sunday newspaper. From my observation, Sunday editions are sometimes analytical and may topicalize an issue that is not necessarily current. Topicalization is a style that serves to 
highlight an issue raised as important and influence readers to make a similar stance. Hence by topicalizing the issue of the president as being in debt, the Sunday Standard seeks to persuade its readers to view the president as described and presumably also influence their political alignment.

In the headline A man with one option, the reference to Kibaki as 'a man' in this context gives him an identity of ordinary human being, not a president. The story was written in the context of disagreement between the president and the prime minister on Muthaura as head of public service. The opening paragraph reads of the story reads:

\section{President Kibaki ventured out of state house a day after Parliament rejected his appointment of Justice Aaron Ringera, but kept his next course of action to himself. (Text31)}

The use of 'venture' alludes to risk and gives the idea that the political atmosphere is very hostile to the president. This line of thought continues in the story with the writer stressing the point that the president's political options are limited.

But as he went about his work, one thing stood out: On Wednesday evening, Parliament made him the first President to have his executive authority challenged by the House and made a study in how the Legislature can neutralize theso-called imperial powers, leaving him with zero option. (Text 32)

The use of the evaluative expression, 'so-called imperial powers' and 'zero option' bring out the writer's disdain on the person of the president and the ideological stance on the political situation is expressed. That the action of the president is seen to have 'made a study' is a pointer to the level of commitment that the writer has in his displaying the president as a failure. Indeed, in one of the paragraphs in the body of the story, the president's options in the quagmire is in form of reported speech from a university don that echo the conventional words pronounced to a suspect when arrested by a policeman:

University of Nairobi political scientist Adams Oloo said the president has three options: To choose to remain silent, await a court verdict on pending matters or prevail upon Ringera and his two assistants to resign, and reapply through the board.(Text 33)

The image of 'prisoner' or a criminal who has finally been caught as the above text shows is a clear indication of the paper's attitude towards the president. It is not a neutral representation of issues. The tone of the story serves to bring out a negative image of the president through chosen lexicon and the general structural design of the texts. Attributes by media contribute to the formation of attitudes towards the object of the reference (van Dijk, 1995). This means that the identities the media gives personalities affect the way they are viewed and this in turn can have political consequences.

\subsection{Kibaki as Opportunistic and Self-preserving}

President Kibaki sometimes came across as one who made relationships purely for political expediency and self-preservation. The Standard headline story Ruto walks into Kibaki's den ${ }^{\mathbf{1 0}}$ exemplifies such evaluation of the president. In the literal sense, the headlin paints the image of the president as a dangerous cannibal luring its unassuming prey to its destruction. This was in the context of the agriculture minister breaking ranks with his former ally, the PM. The headline is reinforced by the image of the two leaders at the back of a presidential land rover and with the front part of the vehicle not visible, it looks like a den. Ruto was a relatively young politician and the impression created is that Kibaki is taking advantage of him for selfish political gain. The metaphor of the 'den' and its accompanying image are part of the negative portrayal of the president by The Standard newspaper as part of its persuasive rhetoric about the state of affairs in Kenyan politics. The opening paragraph of the story describes the apparent new friendship between the president and the agriculture minister thus:

President Kibaki and Agriculture Minister William Ruto rode on the shiny Commander-in-chief's ceremonial Land Rover last week, calmly waving at the crowd. (Text 34) 
The adverb 'calmly' is evaluative in the sense that the writer wants the reader to find it odd that the two should look 'calm' together and reinforces the fact that Ruto is changing his political alliances which the writer thinks spells doom for him. But the critical aspect of the story lies in its assumption that the interpretation of the political developments involving Ruto is shared across the populace as the following texts show.

The occasion was the opening of Eldoret Agricultural show but the political symbolism of Ruto and Kibaki's sense of ease with each other was not lost to discerning students of Kenya's dynamic politics (text 35)

What was a routine agricultural trade fair has reignited debate on who between Ruto and Kibakiis wooing the other. It has also triggered questions on the possible impact of what some Kalenjin MPs call newfound 'friendship' with kibaki on the pre-2012elections alliance building. (Text 36)

And most poignantly, it has sent tongues wagging on Kibaki'spossible role and Expectation in the Kikuyu-Kalenjin-Kamba Alliance whose initial plotters said was the platform for Vice President Kalonzo Musyoka, Deputy Prime Minister Uhuru Kenyatta and Ruto. (Text 37)

In the texts 35-37, the paper attempts to democratize the interpretation of the political scene by presenting its views in such a way as to suggest that the views are shared by many people in order to make them credible. In text 35 , for instance, the paper makes reference to an amorphous group of people dabbed 'discerning students of Kenya's dynamic politics' who saw the 'symbolism' in the president's and the agricultural minister's ride in one Land Rover. Text 36 makes reference to 'reignited debate' and 'triggered questions' and in text 36 we have the intensification in 'most poignantly' to emphasize the degree of emotional involvement in some undisclosed 'discursive sites'. In the absence of the identities of the participants in the social debate, the texts seem aimed at showing that the views given have a discursive element and hence valid.

As the story develops, the imagery of the 'den' is extended in the claim that the agricultural minister has drifted away from the safety of Raila Odinga's 'armpit' as in this text:

Ruto, who has been drifting away from Raila Odinga's armpit kicked

off the week with a message to Rift Valley leaders to turn up in large

numbers to welcome Kibaki (Text 38)

The image of the 'armpit' serves to bring out the identity of Ruto as weak and vulnerable hence the need to be under Raila's protection as well as showing Raila as a protector and a safe haven for Ruto. It also reinforces the image of political cannibalism attributed to president Kibaki in whose den Ruto will perish.

In another headline, Why Kibaki allowed Raila to sack Ruto, ${ }^{11}$ the character of the president is shown as self-preserving. The structure of the headline is a wh- cleft construction where the focus of the clause is the missing crucial information that the writer purports to reveal and is meant as bait to get people to read the story as discussed in chapter 4 . Immediately below the headline, at the billboard, the newspaper, in big font, summarizes Kibaki's reason for allowing Ruto to be sacked thus:

President wants to keep off succession politics and use his last year in office to safeguard his legacy, thus the warm working relationship with PM. (39)

As the story develops, it is apparent that the self-preserving character of the president as depicted in Daily Nation is not negativized. The writer rationalizes Kibaki's move as one that 'demonstrated Mr. Kibaki's complex approach to politics and his manoeuvres to protect his legacy'. As has been observed in this study, the Daily Nation did not explicitly describe the president in negative terms even when the newspaper raised issues with some of his decisions. The explicit negativization of the 
president's character was done by The Standard as analyses have shown. In the last paragraph of the story, the writer alludes to the president's seeming guarded character.

The latest changes, which flew against received wisdom among the political elite, has shown the President retains his capacity to baffle analysts and pundits and his behaviour in the run-up to the battle for succession will remain one the fascinating elements of the 2012 elections (40)

From the description of the president as one who 'retains his capacity to baffle analysts' and terming of his reserved character as 'fascinating', it is clear that although Kibaki comes across as selfpreserving, the newspaper presents it as a positive trait.

\section{CONCLuSiON}

In this article, I have attempted to categorize identities for the two principals of the grand coalition government, drawing from the language the newspapers used to represent the characters.The Standard is seen to be explicit in its negative depiction of the president while portraying the PM in more favourable terms. The Daily Nation avoids explicit evaluation of the two political leaders. The PM is described in positive terms especially by The Standard newspaper which depicts him as a selfless hero who could deliver great things but also as a victim of negative forces in the government. He is also portrayed as a peace maker quelling tensions that arise in the coalition. The president on the hand comes out as an ineffective leader, a non- reformist, opportunistic and self-preserving. In evaluating political leaders in particular ways, the newspapers make their ideological stance known on as far as the country's leadership is concerned. The Standard newspaper views the President as one who is not capable of leadership. The evaluative lexicon, the schematic form of the stories, the metaphorization of the character of the Prime Minister and quotation of 'expert' opinion, are some of the discourse strategies used by the newspapers to persuade and maintain a political ideology, namely; the Prime Minister is a better leader for Kenya. Although we cannot empirically show the influence media reports has on people attitudes and opinions in social and political matters, there is a general agreement that media can influence what people think and do. The media's potential to influence people is acknowledged by discourse analysts such as Develotte, \&Rechniewski(2001),Juan Li (2009) and Van Dijk(2008). Media's influence lies in its symbolic power since the power cannot be exercised directly on people. Van Dijk (2008: 10) calls it 'social power' and defines it as 'a social relation between groups or institutions involving the control by a (more) powerful group or institution of the actions and the minds of a less powerful group'.This being the case, assumptions can be made on the magnitude of the influence of the newspapers' depiction of the two principals and the possible political implications of such depiction.

\section{REFERENCES}

Frogner, T. (1999).'European Identity - a perspective from a Norwegian European, or a European Norwegian'.In Jansen, Thomas (ed.) Reflections on European Identity. Brussels: European Commission Forward Studies Unit Working Paper.

De Fina, A. (2011). 'Discourse and Identity'. In van Dijk (ed) Discourse Studies A multidisciplinary introduction. London: Sage pp.263 - 281.

Van Dijk, T.A. (1998).'Opinions and Ideologies in the Press' Paper Round Table on Media Discourse, Cardiff, July 8-10, 1995. Published in Allan Bell and Peter Garrett (Eds.), Approaches to Media Discourse.(pp. 21-63).Oxford: Blackwell

Hardman, D. (2008). Political Ideologies and Identity in British Newspaper Discourse Ph.D. thesis

Althusser, L (1971) 'Ideology and Ideological State Apparatuses' in L. AlthusserLenin and Philosophy and other Essays. London: New Left Review.

Trömel-Plötz, Senta: "Selling the Apolitical". In: Coates, Jennifer (ed.) (1998): Language and Gender: A Reader. Oxford: 446-458

Yieke, F.A (2007).'Gender and Topic Management in Discourse: The Glass Ceiling a as Reality for Women in Corporate Kenya' Stichproben Wiener Zeitschrift fur KritischeAfrikastudien $\mathrm{Nr}$ $13 / 2007,7 \mathrm{Jg}$

Ndambuki, J. (2010). Political Discourses, Women's Voices: Mismatches in Representation. Critical Approaches to Discourse Analysis across Disciplines Vol 4, 173-92 
Chilton, P. \&Schaffner, C. (2011). 'Discourse and Politics'. In: van Dijk, T. (ed) Discourse Studies: A multidisciplinary introduction. London: Sage pp. 303-330

Van Leeuwen, T.(2007). 'Legitimation in discourse and communication'. Discourse and Communication, 1 (1): 91-112

Juan Li (2009).'Intertextuality and National Identity: Discourse of National Conflicts in Daily Newspapers in the United States and China'. Discourse and Society 20, 85-120

Biber, D., et al (1999). Longman grammar of spoken and written English. Essex: Longman.

Herman, E.S. and Noam, C. (1988) Manufacturing Consent: The Political Economy of the Mass Media. New York: Pantheon.

Fairclough, N. (1995a). Media Discourse. London: Edward Arnold

Brownlie, D. and Home, S.(1999), "Consumption curtailed: an exploratory study of identity and exchange in a penal environment", Advances in Consumer Research, Vol. 26 Issue 1, p.231-235

Moufahim, M. (2007) Interpreting Discourse: A Critical Discourse Analysis of the Marketing of an Extreme Right Party, TheVlaams Blok/ VlaamsBelang

Van Dijk, T.A. (1995). 'Discourse Analysis as Ideology Analysis in' C. Schaffner\& A. Wenden (eds) Language and Peace (pp 17-33) Aldershot: Dartmouth Publishing (Unpublished thesis).

Develotte, C. and Rechniewski, E. (2001) 'Expressions de l'identité nationale dans les titres de journaux: une étude comparative de journaux français et australians pendant une période de crise', in Malewska-Peyre, H., Tanon, F. et Sabatier C (eds), Identité, Altérité, Acculturation. Perspective francophone, Paris, L'Harmattan

Van Dijk, T.A (2008) News, discourse and ideology. In ThomaszHanitzsch\& Karin Wahl-Jorgensen (Eds.), Handbook of Journalism Studies. (pp. 191-204). Hillsdale, NJ: Erlbaum

Appendix: Newspaper Headlines Stories Analyzed from The Standard andDaily Nation

[1] The return of Raila (The Standard, 20/4/2008)

[2] Raila on Kibaki (The Standard, 10/1/2009

[3] Was this man given a long rope to hang? (The Standard ,21/8/2009)

[4] Why they want Raila out(Daily Nation, 6/2/2011)

[5] Will Raila survive Kibaki's Mr. Fix it? (Daily Nation, 27/2/2011)

[6] The Battle goes to parliament (The Standard, 18/2/2010)

[7] Raila urges calm as PNU plots offensive (Daily Nation, 31/1/2011)

[8] A president in debt (The Standard, 1/3/2009)

[9] A man with one option (The standard, 18/9/2009)

[10] Ruto walks into Kibaki's den (The Standard, 15/3/2010)

[11] Why Kibaki allowed Raila to sack Ruto (Daily Nation, 28/8/2011)

\section{AUTHORS' BIOGRAPHY}

Mary Karuri, teaches linguistics in the department of arts and humanities of Chuka University.

Prof Peter Muriungi, is an associate professor of linguistics in the department of arts and humanities of Chuka University 